\title{
OBSERVATIONS ON THE
}

\section{BRAZILIAN PRESIDENCY,}

\section{DEMOCRACY, AND}

\section{GOVERNANCE}

Kurt E. von Mettenheim

Professor at EAESP/FGV.

\begin{abstract}
RESUMO
Este artigo apresenta os primeiros resultados de uma pesquisa sobre a administração da Presidência brasileira e problemas de governança democrática no Brasil. São criticados viéses eurocêntricos nas análises de presidencialismo, democracia, governança e representação, e são propostas novas análises comparativas de experiências políticas nas Américas. Esta análise da Presidência brasileira revela novos padrões de representação determinados pelo Executivo e um novo estilo de governança aberta e pluralista no recente período de pós-transição.
\end{abstract}

\section{ABSTRACT}

This article presents the first results of research on the organization and administration of the Brazilian presidency and problems of democratic governance in Brazil. Biases of Euro-centrism in current views of presidentialism, democracy, governance, and representation are criticized and new comparative analysis of political experiences in the Americas called for. Initial analysis of the Brazilian presidency reveals a unique combination of executive-led electoral representation and muddling through governance since the transition from military rule.

PALAVRAS-CHAVE

Política, governança, Presidência, democracia.

KEY WORDS

Politics, governance, presidency, democracy. 


\section{INTRODUCTION}

The collapse of the Soviet Union culminated a remarkable series of transitions from military, authoritarian, and Stalinist rule. The sheer number of new nation-states and the daunting complexity of the post-transition and post-Cold War world suggest that our fin-de-siecle will be remembered as a remarkable period of political change. While a rich diversity of scholarship on democratic transitions and their legacies exists, ${ }^{1}$ this paper argues that political scientists need to more carefully consider new developments in the global south and east, and that the Brazilian experience is uniquely suited to provide new concepts and theories about democracy and governance. New work is needed because existing theories and concepts about presidentialism (Linz \& Valenzuela, 1994; Mettenheim, 1997), democracy, ${ }^{2}$ governance, ${ }^{3}$ and economic policy ${ }^{4}$ tend to underestimate the importance of new patterns of change in Brazil and other post-transition contexts. Unfortunately, biases of Euro-centrism and liberalreformism too often lead social scientists to expect post-transition politics to repeat European or North American experiences.

The first meeting of the Associação Brasileira de Ciência Política is a notable forum to present several observations about the presidency, governance, and economic policy. ${ }^{5}$ My attempt here is to combine a positive account of party-electoral politics in Brazil with a pluralist conception of muddling through policy making. The central argument about presidential governance can be stated as follows: It is politics, not economics, that explains the successful reduction of inflation in post-transition Brazil. It is the open, inclusive, negotiated, and incremental character of policy making that explains the ability of the Franco (1992-1994) and Cardoso (1994-present) administrations to reduce high inflation while, at the same time, increasing the real wages of poor Brazilians. ${ }^{6}$ Given the tendency to view democracy and effective economic policy in zero-sum terms, and wage austerity as necessary to reduce inflation, this is a remarkable achievement. And although credit is due to theories of inertial inflation ${ }^{7}$ for clarifying the new causes and contexts of prolonged high inflation, the successful reduction of inflation in Brazil depended on a more open, pluralistic style of muddling through governance to implement policy. Indeed, muddling through has defined policy successes and statecraft during and after transitions from authoritarian rule throughout Latin America. As Mettenheim and Malloy (1998) note:
Whatever novelties have emerged from within these (Latin American) countries in terms of regime form and practice has taken shape out of the accumulated weight of skillful statecraft which finds its way from one problematic situation to the next. Grand solutions based on theoretical design, strategies derived from formal instrumental rationalities, and broad constitutional engineering have fallen far short of this creative statecraft of muddling through.

This paper attempts to combine the electoral realism of competitive democratic theory with a liberal-pluralist conception of governance to emphasize the novel patterns of political change that have emerged in posttransition Brazil.

Most observers misunderstand Brazilian politics because of Euro-centric and liberal-reformist biases. Although further analysis will be required, note the following examples from scholarship in three subfields of political science. First, despite considerable debate about institutional design in post-transition settings, critics of presidentialism have left us without a positive theory of political change within these systems. Scholars such as Juan Linz, Fred Riggs, Alfred Stepan, and Arturo Valenzuela (indeed, including Fernando Henrique Cardoso) have attempted to draw direct causal links between presidentialism and problems of ungovernability, instability, and democratic breakdown (Linz \& Valenzuela, 1994). ${ }^{8}$ Presidential institutions may indeed retain a greater burden of proof because they are fewer in number and can easily be confused with directly elected authoritarian executives. But recent advocates of parliamentarism misrepresent the American experience and its liberal-democratic tradition of separating and diffusing power, fail to provide a positive account of political development within presidential institutions, and tend to overestimate the impact of political reform (Mettenheim, 1997). Presidential government in posttransition Brazil produced, not the gridlock, polarization, corruption, and demagogic populism that critics expected, but new patterns of political change through direct popular appeals, alliances with patronage machines, and movements for political reform. And contrary to the notion that only parliaments tend to remove executives, Brazil's first directly elected president after the transition from military rule was impeached on charges of corruption in late 1992.

To better understand these developments in Brazil, scholars would do well to consider an earlier generation of scholars who broke away from similar biases of liberal-reformism and Euro-centrism to understand political history in the United States. Indeed, social science classics from Max Weber to Carl Friedrich saw the conflict in presidential systems between direct 
plebiscitarian appeals and representative government as central to understanding political development in the United States (Friedrich, 1967). Subsequent scholarship by V. O. Key, W. D. Burnham, William N. Chambers, Theodore Lowi, and others argues that rapid change occurred in the United States during the nineteenth and twentieth centuries largely because of critical elections and party realignments driven by direct presidential elections (ameliorated by the electoral college). ${ }^{9}$ By replacing liberal-reformist and Eurocentric theories about the United States, these empirical analyses provided fundamentally new conceptions of American democracy. A central argument of this paper is that political scientists need to perform a similar conceptual leap to understand the presidency, democracy, and governance in Brazil.

The biases of liberal-reformism and Euro-centrism also prevail among scholars of political parties and party systems. ${ }^{10}$ Understanding political parties in Brazil requires shifting away from models based on the rigid parties and parliamentary systems of midcentury Europe. The alternative "American" trajectory of party development has also been widely noted since the social science classics. The American experience was driven largely by the power of American presidents to nominate party professionals to administrative posts and thereby create alliances with patronage systems of Senators. ${ }^{11}$ Consequently, scholars of American parties emphasize the direct popular appeals of presidential elections rather than the rationality of party programs, argue that patronage machines may be rapidly transformed into mass parties through nominations and alliances, and focus their research on the electoral practices of party professionals rather than ideal organizational characteristics or concepts of party discipline or fidelity. ${ }^{12}$ In sum, scholars who criticize political parties in Brazil today for exacerbating patronage, corruption, and legislative indiscipline (like advocates of the responsible party system model in the United States four decades ago) fail to recognize alternative trajectories of change outside a liberalreformist model based largely on the Westminster experience. ${ }^{13}$

Finally, the subfield of electoral behavior also requires open-ended empirical research to surpass similar problems of Euro-centrism and liberalreformism. Analysis of Brazilian public opinion suggests that perceptions and preferences among
Brazilian voters are indeed more direct, unmediated, and volatile than their European and North American counterparts. But difference does not imply dysfunctionality. Traditional measures of voter choice fail to describe the conceptual content and political

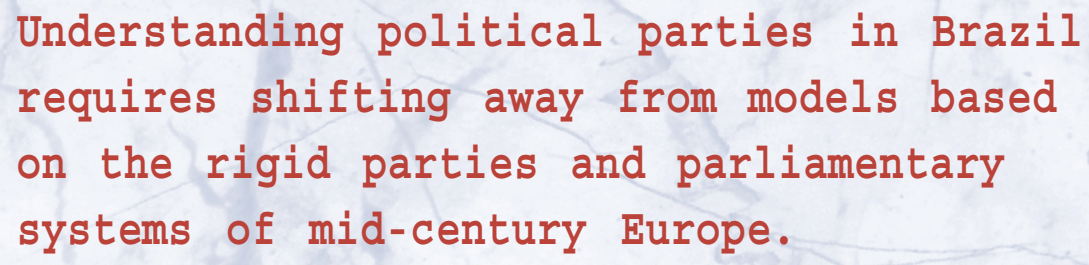

context of Brazilian voters because they are designed to tap European ideologies or American notions of group-interest. ${ }^{14}$ Questionnaires and concepts based on national experiences in the North Atlantic simply fail to describe how Brazilians think about politics and vote. My recent research suggests that national electoral contests and feedback mechanisms of power (also emphasized in recent mass belief studies) informed Brazilian public opinion more than ideologies from Europe or notions of group interest from the United States. ${ }^{15}$ The greater transparency, immediacy, and volatility of Brazilian public opinion appear to be both cause and consequence of the different trajectory of change in Brazil.

In sum, both core conceptions of democracy and scholarship in the subfields of electoral behavior, party systems, and institutional design often succumb to "illusions about consolidation" based too exclusively on a liberal-reformist account of North Atlantic experiences (O'Donnell, 1996, p. 38-9). Guillermo O'Donnell suggests that concepts of consolidation and institutionalization may mislead empirical research by defining post-transition cases negatively; ${ }^{16}$ by using idealized yardsticks extracted from European experiences; ${ }^{17}$ and labeling national experiences that do not take expected paths as "stunted, frozen, protractedly unconsolidated, and the like" (O'Donnell, 1996, p. 38). This paper attempts to rise to O'Donnell's challenge - that scholars capture new patterns of posttransition change and provide positive comparative references for "a non-teleological and indeed, nonethnocentric, positive analysis of the main traits of these polyarchies" (O'Donnell, 1996, p. 46).

A particular concern about the legacies of transition should also be noted. As early as 1987, James Malloy (1987) warned that recent transitions in Latin America might simply graft more or less competitive elections onto the centralized executives left by military or 
authoritarian rulers. O'Donnell (1996, p. 44) argues that this excessive power of post-transition executives combines with rampant particularism to create a new kind of delegative democracy:

The combination of institutionalized elections, particularism as a dominant political institution, and a big gap between the formal rules and the way most political institutions actually work makes for a strong affinity with delegative, not representative, notions of political authority. By this I mean a caesaristic, plebiscitarian executive that once elected sees itself as empowered to govern the country as it deems fit.

The implications are considerable. The absence of control mechanisms or checks and balances on executives who claim to act for some unitary general will or national interest suggests that a new form of delegative democracy threatens to predominate in posttransition contexts. And because delegative democracy fail to provide opportunities for access, feedback, and political negotiation with executives after elections, these new executive-centric patterns render theories of democratic consolidation premature and misleading.

This concern about centralizing power in the executive also resonates with classic accounts of Brazilian politics. Indeed, a glance through Brazilian history suggests that new political institutions were often grafted onto its hierarchical society with unexpected results. Observers of the Brazilian Empire (1822-1899) argue that rural patriarchs simply reorganized their clientele into voting blocks after Dom Pedro I founded free-male suffrage in $1824 .{ }^{18}$ Writers of Brazil's first republican constitution in 1891 attempted to decentralize Imperial power by adopting federal institutions from the United States. However, governors (entitled Presidentes) rapidly asserted their dominance and created single stateparties. ${ }^{19}$ After Getulio Vargas' Estado Novo (19371945) centralized government and organized working class and popular sectors into corporatist institutions, the period of competitive politics which followed (1945-1964) once again reflected the grafting of competitive elections onto centralized policy making styles. Souza argues that the irresponsible leadership that led to democratic breakdown in 1964 can be traced to this lack of access by party politicians to key policy decisions. Because core issues of economic policy remained under the control of presidents and their policy teams, legislators and party politicians were reduced to populist promise and the traffic of patronage (Souza, 1976). The transition from military to civilian rule (1974-1985) lasted so terribly long in large part because more or less competitive elections for legislative offices were grafted onto military control of executive offices. ${ }^{20}$ While this paper recognizes the executive-centric legacies of Brazilian history, the argument is that new, more open, pluralistic, and muddling through policy styles have emerged since the transition from military rule.

The separate discussion of executive-led electoral representation and muddling through governance that follows reflects universal concerns about liberaldemocracy. For the liberal tradition conceives of representation in two recurrent and quite different moments: first the selection of representatives through competitive elections and second a more vaguely shaped process whereby representatives transact with social interests to produce public policy. During elections, representation is conceived of in geographical terms as the articulation of individual preferences. After elections, questions of representation shift to functional images of pluralism, of a mobilized civil society, of organized interests that attempt to impact state bureaucratic politics and the need for a transparent, muddling through style of policy implementation.

\section{EXECUTIVE-LED REPRESENTATION}

The power of direct appeals to voters by executives has been the most important phenomena of electoral representation in post-transition Brazil. Indeed, presidents have won office across Latin America by bypassing traditional partisan attachments and appealing directly to voters. In Argentina, both Presidents Alfonsin and Menem won by cross-cutting the traditional Peronista/Anti-Peronista cleavage which had dominated politics since the 1940s. ${ }^{21}$ In Mexico, after the monolithic PRI (Partido Revolucionário Institutional) was shaken by electoral challenges on the left and right in the 1988 and 1994 presidential elections, Presidents Salinas and Zedillo convinced political elites to pursue new vote-getting strategies through a National Program of Solidarity (PRONASOL) that appealed directly to voters (Kaufman,1996; Camp, 1996). In perhaps the most troubling example, Alberto Fujimori came from outside traditional party organizations to unexpectedly win the Peruvian presidency in November 1991, only to close Congress and impose a state of emergence in February 1992 (Conaghan, 1996; Carrion, 1998). The recent election of Hugo Chavez to the Venezuelan presidency (former leader of attempted military coups) is another compelling example that direct appeals can bypass traditionally well organized parties.

Further consideration of these direct appeals by 
executives is also needed because existing conceptions of electoral representation from Western Europe and North America are seriously impaired. ${ }^{22}$ Classic ideas such as mandate, authorization, accountability, and virtual representation fail to adequately describe how representation works in mass democracies (Pitkin,1968).Theories of geographical and demographic representation are insufficient because public perceptions now crosscut traditional cleavages of class and region. ${ }^{23}$ Political parties no longer retain the near monopoly on governance typical of competitive party systems for much of the postwar period (Sartori, 1976). And popular identifications with parties no longer provide the strong links they once did because both direct appeals during elections and the traffic of interests afterward bypass these partisan attachments. Finally, studies of public opinion in North America and Europe now emphasize the importance of top-down appeals, the reality of feedback mechanisms that make those in power popular, and the existence of other reciprocal patterns among voters. All of these developments are at odds with formal liberal views of electoral representation as the unilateral articulation of preferences from the bottom up.

Scholars of advanced democratic electorates tend to explain top-down influences by referring to elite leadership, to irrational psychological processes among voters, or to the manipulation of public opinion through techniques of marketing, public relations, and polling. Competitive theories of democracy are accurately labeled elite theories because scholars believe that elites must form public opinion and influence voter alignment. ${ }^{24}$ Landmark contributions from Adorno (1950), Lane (1962), and Noelle-Neumann (1984) suggest that the excessive influence of elites and other top-down realities in public opinion are caused by irrationalities among voters, whether low ego-strength, repression, displacement, or other underlying psychological mechanisms. Recent critical accounts of public opinion argue that party elites in centralized campaign organizations increasingly manipulate voters through improved technologies of political marketing. ${ }^{25}$ While these perspectives are certainly insightful and relevant in the Brazilian case, emphasis on elite leadership, mass psychology, and technologies of manipulation fails to fully develop the implications of immediate and personalistic conceptions of politics among Brazilian voters, and the reality of direct popular appeals and patronage machines in Brazilian party-electoral politics.
As noted above, most measures of political sophistication in electoral behavior studies fail to describe changes among Brazilian voters because they are designed to tap European ideologies or American notions of group-interest. According to existing (and widely debated) levels of conceptualization scales, the cognitive content of Brazilian survey respondents can only be described by placing responses in residual

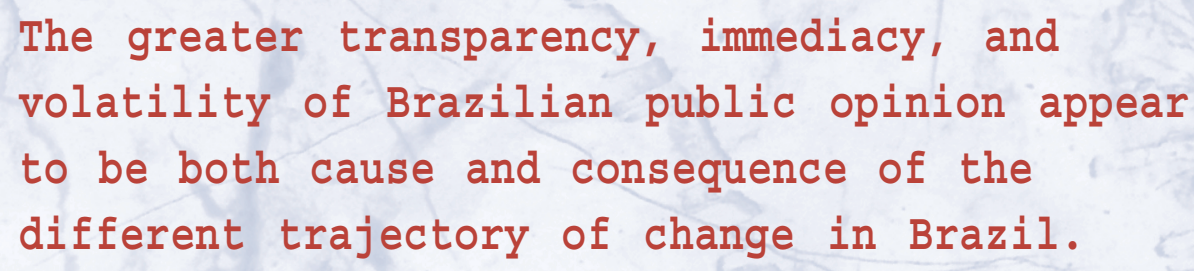

categories such as "nature of the times" or "no content". However, if one unpacks the immediate and personalistic conceptions of politics which predominate among Brazilian voters from within these residual categories, recent empirical research reveals a fundamentally new causal sequence in Brazil: Voter choice is organized by perceptions of executive performance and positions on the national issues of the day, and grounded in conceptions of substantive justice rather than determined by long-term factors such as political socialization, class identity, or party identification. ${ }^{26}$ New concepts about electoral representation and democracy are needed to describe the implications of this sequence. And the problem cannot be disregarded as Brazilian exceptionalism. Complex reciprocal effects, top-down appeals, and feedback mechanisms of power are also emphasized in recent empirical studies of electoral behavior. ${ }^{27}$

The concept of executive-led representation attempts to capture the reality that perceptions and preferences among Brazilian voters are direct, unmediated, complex, changing, populist, and personalistic, but nonetheless linked to matters traditionally associated with democracy such as direct popular appeals and conceptions of substantive justice. Indeed, the Brazilian experience may be of considerable relevance elsewhere, given the inability of social scientists to fully describe politics after the dealignment of modern, class based cleavages. In Brazil, short-term perceptions of voters directly judge parties, national issues, and executive performance, without the moderating influence of civic culture, long-term political socialization, deep class identities, traditional political ideologies, or party identification.

This argument about electoral behavior also implies a different view of party-electoral politics in Brazil. 
Contrary to widespread assertions that Brazilian parties remain underdeveloped, this paper argues that the executive-centric presidential and federal system of Brazil facilitated the direct nomination of party professionals to executive posts and administrative offices during the transition period and thereby produced a rapid and sweeping organization of mass parties. As argued above, this experience is not without precedence. The American experience (especially before progressive-era legislation weakened parties) is a more adequate reference because it directs attention away from the organizational structures of parties and toward their electoral practices. W. D. Burnham (1970, p. 10) argues that: “... it is of importance to note that the term (party system) relates primarily to what might be called voting systems or electoral-politics systems rather than to organizational structures."

From the acute observations of Max Weber and James Bryce to more recent "new political historians," 28 central aspects of American exceptionalism have been defined in terms of its sequence of party systems; the precocious emergence of mass parties, the predominance of pragmatism, patronage, and a spoils system over ideology, the impact of a presidential instead of parliamentary system, and the importance of federalism in a new and large country. ${ }^{29}$

Three aspects of American party development provide a fundamentally new perspective on partyelectoral politics in Brazil: (1) the importance of direct popular appeals and populism in presidential systems; (2) the capacity of presidents and other executives to directly nominate partisans to administrative posts, and; (3) the autonomy of local and regional patronage machines under federalism. Can this trajectory of change be called democratization? Positive and negative views of party politics deeply divide recent debates about populism, patronage, and mass inclusion in nineteenth century America. Given this polarization, a return to Max Weber's classic description of American party development as passive democratization is attractive because it distinguishes the analytic task of identifying new emergent characteristics in politics from the equally important but distinct consideration of their normative implications. ${ }^{30}$ Indeed, these mechanisms of party development (lamented by many in the United States) are even more melancholic in Brazil. Both the plebiscitary appeals of presidential elections and the reorganization of patronage systems into mass parties appeared extremely late in Brazilian history. Furthermore, political parties, public opinion, and patterns of governance recently emerged from under military rule in the context of an extremely state-centric society with one of the worst disparities of income in the world. These differences suggest that recognizing new patterns of change must be followed by realistic programs for political reform.

In terms of generating new political leadership, this shift in comparative perspective casts recent developments in a new light. Indeed, the 1994 presidential campaign brought to the fore two of the most important new independent leaders of opposition to military rule in Brazil. After first confronting the military regime by leading metalworker strikes in São Paulo's industrial suburbs in the late 1970s, Luiz Inácio da Silva (Lula) founded and helped lead the Worker's Party (Partido dos Trabalhadores, PT) into the principal force on the left in Brazilian politics during the 1980s and 1990s. ${ }^{31}$ Fernando Henrique Cardoso's trajectory is no less innovative. An internationally recognized academic, Cardoso first stepped from sociology to the Senate in 1982 and became a central figure negotiating transition from military rule (1985) and writing the 1988 Constitution. After machine politicians led by Orestes Quércia (São Paulo Governor 1986-1990) asserted control over the national directorship of the PMDB in 1988 (in expectation of dominating the 1989 presidential race), Cardoso split to found the Party of Brazilian Social Democracy (PSDB) along with other PMDB centerleft dissidents. In comparative and historical perspective, the emergence of a reform president and an independent-left Worker's Party as loyal opposition as the two central political forces in Brazil after transition from military rule are notable developments. The consecration of Lula and Cardoso in the 1994 election suggests that the traditional mechanisms of party-electoral politics in Brazil may provide the setting for the emergence of new leaders and the implementation of economic and political reforms.

In 1994, the traditional mechanisms of partyelectoral politics in Brazil - direct popular appeals and alliances with patronage machines - accurately describe Fernando Henrique Cardoso's ability to win the presidency in first-round voting on November 15 . Both the electoral alliance and governing coalition between Cardoso's PSDB (Partido da Social Democracia Brasileira) and the conservative PFL (Partido da Frente Liberal) have received significant criticism from partisans, journalists, and Brazilian intellectuals. Even Cardoso's 1994 campaign manager feared that because of the traditional conservative character of the PFL, core supporters from southeast urban areas would shift to the Worker's Party if the campaign had gone into a second round. ${ }^{32}$ However, 
these concerns in June 1994 soon gave way due to the successful reduction of inflation, the immense popularity of the newly stabilized currency (Real), and the significant redistribution of wealth secured by government policies.

The lack of political resolution before 1994 arose in great part because the 1989 presidential contest was held outside the historical norm and in isolation from legislative and gubernatorial elections. The central principle behind Assis Brasil's formula for electoral representation is to counter the plebiscitarian tendencies of direct executive elections by combining separate election of legislators through quite liberal rules of proportional representation. ${ }^{33}$

Fernando Collor de Mello (a relatively unknown governor from the small northeast state of Alagoas) was thereby able to dominate the first six months of the campaign through television appearances and denunciations of bureaucratic abuse. After Collor reached over 45 percent in preference polls by June, he refused to participate in the live television debates of the first round (accurately reflecting the damaging prospects of sustained attacks from adversaries). Collor won over 28 percent in first round voting, with Inácio da Silva (Lula), the candidate for Partido dos Trabalhadores (Worker's Party, PT) entering the runoff election with 16 percent. While Lula dominated the first television debate of the second round and surged in the polls to tie Collor only ten days before the December 15 vote, the Worker's Party candidate failed to dominate the second debate as he did the first and was unable to counter the damaging effect of negative advertising in the final days of the campaign. Collor convinced voters that a victory of Luiz Inácio da Silva and the PT would destabilize society and turn Brazil away from a liberalizing world by mounting a series of personal and political attacks seven days before the final election. On December 15, Collor received $35,089,998$ votes (42.7 percent), defeating Lula with $31,076,364$ votes (37.8 percent).

The sheer velocity and range of fluctuations among voter's intentions during recent presidential campaigns suggest the more volatile, plebiscitarian, executivecentric character of electoral representation in Brazil. During the 1989 contest, Fernando Collor de Mello's ratings in the polls rose rapidly to 45 percent, then fell to 28 percent in the first round. In 1994, Worker's Party candidate Luiz Inácio da Silva fell from a high point of 42 percent in polls taken on 1 May to 22 percent in a poll on 30 September, accurately reflecting his final share of the vote. Fernando Henrique Cardoso's trajectory in opinion polls from 16 percent of voters preferences on 3 May to 48 percent on 30 September is even greater. During the 1998 contest, Fernando Henrique Cardoso started at 41 percent of voters' preferences in late April, dropped to 33 percent in late May, and increased steadily thereafter until receiving 55 percent of votes in the first round on October 3. This velocity and range of change among voters intentions in Brazil is considerably greater than the glacial shifts of between 3 to 5 percent which traditionally occur during national electoral campaigns in Europe. ${ }^{34}$
The power of direct appeals to voters by the most important in post-transition Brazil.
In sum, electoral representation in Brazil is more direct, unmediated, fluid, and both tied to political personalities and underlying conceptions of substantive justice. While the populist tradition endowed Brazilian state-society relations with this greater transparency and immediacy, these characteristics are not simply a consequence of the nations past. Recent universal trends toward direct popular appeals by executives and media-oriented electioneering means that voters now tend to judge candidates, issues, economic performance, and political parties directly, without the moderating influences so important in the past such as political ideologies, notions of group interest, or other longterm identifications with party or class. ${ }^{35}$ The liberal and democratic tradition needs to consider more carefully the implications of direct popular appeals for conceptions of electoral representation.

\section{PRESIDENTIAL GOVERNANCE AS MUDDLING THROUGH POLICY MAKING}

New concepts are also needed to describe new patters of presidential governance in Brazil. After an initial period of caretaker government under President Jose Sarney from 1985-1989, and a period of plebiscitarian adventurism with President Fernando Collor de Mello from 1990-1992, the Franco (19921994) and Cardoso (1994-present) administrations have pursued new patterns of open economic policy making. 
After a decade of high inflation, foreign debt, and negative per-capita growth, the success of gradual, inclusive, and transparent approaches to policy making suggests that open, pluralistic governance and effective economic policy are compatible. ${ }^{36}$ Moreover, the failure of seven economic packages from 1985-1994 to reduce inflation, adjust the economy, and provide sustainable growth suggests that centralized policy making by technocratic teams of economists in executive offices failed to secure the political

(confiscated savings were returned), faced virtually no congressional or social opposition, and overrode governors who were more concerned about succession in their states than organizing national opposition at the end of their term. But President Collor's policy achievements were only temporary. A central cause of returning inflation was the inability of President Collor to secure a national agreement on wage and price guidelines with business and labor in September 1990. ${ }^{37}$ In sum, while the economics were right, the politics were wrong. The failure of President Collor's bold policy initiatives arose from his inability to maintain intermediary links between state and society through negotiations with political parties, and interest organizations of business, labor, and other groups.

$$
\text { President Collor's }
$$

conditions for policy implementation. All seven economic packages were designed in secret and announced unexpectedly to shock inflationary expectations, freeze prices and wages, and halt speculative market forces in financial and currency exchange markets. Although plans and their economic consequences differed, a common and critical weakness was their lack of support among politicians, the business community, labor, and (after the 1986 Plano Cruzado under José Sarney) an increasing popular cynicism about dramatic economic initiatives.

For example, the Collor administration (1990-1992) revealed both the power of presidents to initiate policy and the need to negotiate with political and social actors. At inauguration in March 1990, Brazil faced near hyperinflation and its first decade of negative percapita growth since 1945. Nine months later, few doubted the ability of Brazilian presidents to initiate and implement policy. President Collor reasserted executive authority and shocked investors on 16 March 1990 (the day after inauguration) with a comprehensive plan to reduce inflation, lower the federal deficit, liberalize trade, and modernize the economy. And despite his party's controlling only five percent of the Federal Chamber upon inauguration, President Collor confiscated an estimated 80 percent of Brazil's liquid financial assets by decree. His administration quickly achieved short-term economic policy goals, producing government surpluses, lower interest rates, longer terms for government paper, and a stable exchange rate. Furthermore, the new administration received strong support throughout 1990 from the media and public impeachment in late 1992 suggests that direct presidential appeals must be linked to not only viable policies of economic adjustment, but also sustained negotiations with the diverse representatives of political and civil society. On 29 September 1992 the Brazilian Chamber of Deputies voted 441 to 38 to suspend President Fernando Collor de Mello from office and initiate a formal trial in the Senate, 76 of 81 of whom subsequently voted on December 29-30 for impeachment. ${ }^{38}$ This unprecedented removal of a Brazilian president began in May 1992 when Collor's brother accused the president of extensive involvement in corruption, use of campaign funds for private ends, and participation in the influence peddling organized by his 1989 campaign finance manager. The impeachment of Collor also neutralized campaigns for the adoption of parliamentary government in the plebiscite held on 21 April 1993. Instead, 55.4 percent of voters chose to maintain the presidential form of government, while 66.0 percent chose to maintain a Republic. ${ }^{39}$

Soon after the referendum in which Brazilians chose to retain presidential institutions, Foreign Minister Fernando Henrique Cardoso was called on by then President Itamar Franco (Collor's VicePresident) to accept the Ministério da Fazenda, on 21 May 1993, a post he retained until assuming campaign duties full-time in May 1994. Far from proposing dramatic initiatives or unveiling economic packages, Cardoso sought to assure business leaders and the public that their lives and investments would no longer be submitted to a sequence of government plans which 
tend to radically alter prices, incomes, savings, currency exchange rates, and investment returns. Indeed, by 1993 Brazilians appear to have tired of dramatic initiatives. Since transition to civilian rule in 1985, seven major policy packages and innumerable intermediate adjustments were unexpectedly imposed by the federal government.

Instead, Cardoso adopted a gradualist approach focusing on fiscal reform, monetary restraint, and the need for more transparent public view of the economic policy process. Repeated ministerial appearances in the media assured Brazilians that inflation was high but stable, that the government was not going to freeze wages and prices or confiscate savings, that draconian adjustment policies would be averted. Indeed, the achievements of Cardoso as economic minister often appeared piecemeal, even minor if compared to the dramatic sequence of economic packages preceding his tenure. For example, fiscal reform was first secured by negotiating legislative support for a 15 percent reduction of constitutionally mandated transfers from the federal government to states and municipalities in late February 1994. Cardoso subsequently sought to unify the profusion of financial instruments used as de facto currencies because they index against inflation. The Unidade Real de Valor (Real Value Unit, URV) was designed to become a single measure of inflation that could be readjusted daily by the government.
Focusing the attention of investors and the public on a single government index permitted Cardoso and his economic team to gradually ratchet down inflationary expectations by setting and subsequently meeting realistic fiscal and monetary performance targets. By May 9, Cardoso was able to accompany the announcement that a new currency would be launched on July 1 (made by his successor at the Ministry of Fazenda). This demonstrated once again the effectiveness of publicizing policy measures well ahead of time rather than attempting to shock inflation out of the economy by unexpectedly unveiling secret economic packages. The stabilization of the new currency, the Real, quickly began to symbolize the success of this gradualist approach in reducing inflation and projected Cardoso into the presidential race.

The popular appeal of Cardoso's tenure as Minister was based on the significant redistribution of wealth to poor Brazilians which the Real Plan produced. Not only did inflation fall, but also real wages increased an estimated 20 percent during the first six months after the plan (June-December 1994). Furthermore, the real income of poor Brazilians increased an estimated 50 percent during this period because of the end of inflationary losses to salaries and government efforts to secure the prices of subsistence goods. ${ }^{40}$

Indeed, at an international conference on poverty in Amsterdam, Cardoso's Minister of Education Renato

Figure 1 - Monthly inflation rate

MONTHLY INFLATION RATE (\%)

Comparison with previous stabilization plans

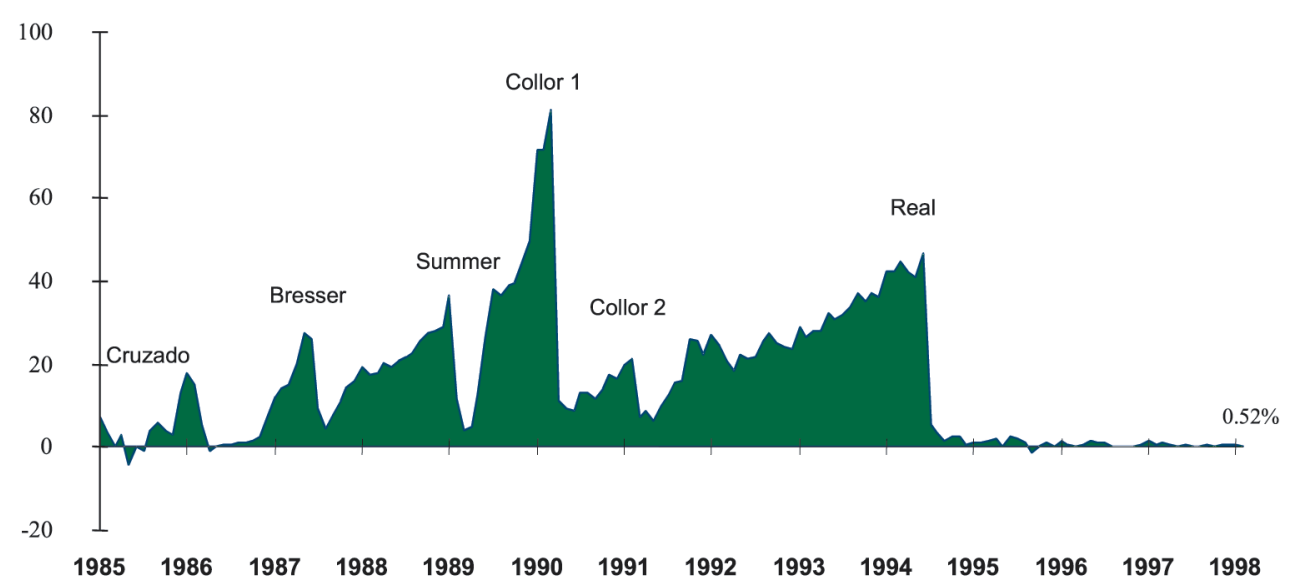

Based on the IPC-FIPE monthly index, January1985 to May 1998. 
de Souza claimed that over 15 billion USD had been transferred from the financial sector to poor Brazilians since the Real Plan reduced inflation. This redistributive impact of economic policy reflects the direct, transparent, and plebiscitarian character of politics in Brazil; economic policy generates widespread public support when it has substantive impact. Given the sustained pessimism throughout North America and Europe about the necessity of incurring high social costs during economic adjustment since the end of Keynesian consensus, the reduction of inflation while positively redistributing wealth is a notable development worthy of greater attention abroad.

Understanding how the Franco and Cardoso administrations reduced inflation without imposing severe measures of fiscal and monetary austerity requires recognition of the specific context and causes of inflation in Brazil. Recent economic theories of inertial inflation, largely based on the persistent high inflation in major Latin American countries during the 1980s, are correct to the extent that they emphasize the indexation of prices, wages, and financial instruments as causes of high and relatively stable inflation. ${ }^{41}$ Since the mid-1980s in Brazil, business, finance, and virtually all asset-holders had shifted assets to savings and investments indexed against inflation. In other words, de facto currencies pervaded the Brazilian economy in the 1980s. Consequently, inflation no longer affected business, finance, and assetholders in ways expected by traditional economic theory. Indeed, the persistent reduction of real wages in the face of high inflation throughout the 1980s and early 1990s was functional for the market economy in the short-term because it transferred wealth away from wage and salary earners and toward asset holders. While theories of inertial inflation correctly identified causes, their new policies failed to keep inflation down because of an exclusive policy making style and the lack of political negotiations to buttress broad plans of fiscal and monetary reform.

In sum, after five years of policy drift, failed packages, and record inflation under the caretaker presidency of José Sarney from 1985-1990 and the false heroics of Fernando Collor de Mello from 1990-1992, the virtues of muddling through permitted Fernando Henrique Cardoso not only to set the stage for reducing inflation without orthodox austerity, but also set posttransition politics on a new footing. And while the considerable popularity of the Cardoso presidency has been built on the redistribution of wealth to the poor during the Real Plan, only time will tell if these onetime gains achieved during disinflation can be converted into more permanent principles and institutions of democracy. Time and further research are needed. But the character of both governance and

Figure 2 - Basic consumer basket and the minimum wage

BASIC CONSUMER BASKET

AND THE MINIMUM WAGE

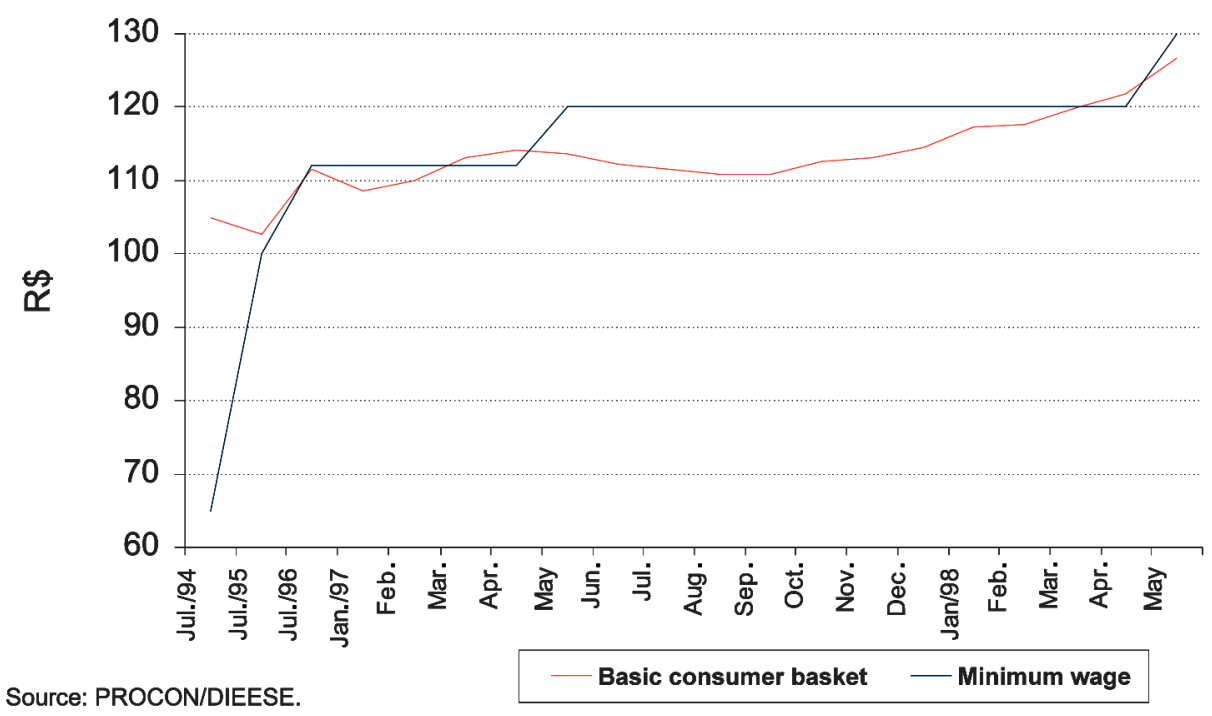


state-led representation in post-transition Brazil differ significantly from existing theories in comparative politics and economics. Contrary to those seeking broad constitutional reform or economic policy-packages (whether neo-liberal or heterodox), and contrary to zero-sum conceptions that set democratization against sound economic policy, recent successes have been based on muddling through. New concepts of statecraft, leadership, political creativity, and governance are required to capture this open, negotiated, and muddling through character of politics and economic policy.

\section{CONCLUSION}

The opportunity to construct cross-national theories about democracy has never been greater. But to meet this opportunity, scholars must avert elevating idealized images of the northwest European experience to measure political change in other regions. Instead, political scientists must conduct empirical research and develop new concepts that communicate new developments in the wide variety of post-transition contexts. Empirical analysis of Brazil has played a critical part in past conceptual breakthroughs with terms such as bureaucratic authoritarianism, dependent development, civil society empowerment, and transitions from authoritarian rule. The first meeting of the ABCP is a propitious moment to challenge political scientists to create new empirically grounded concepts and theories that capture new patterns of democracy and economic policy in Brazil.

The open and pluralist conception of governance at the center of this paper implies that the best policies and practices emerge not from the bureaus of policy planning in Washington, Brasília, or state capitals, but from the day-to-day work of professional politicians, mobilized citizens, and active civil-society organizations. An open, pluralist conception of governance that emphasizes negotiation rather than planning, and the open transaction of social and political interests during policy implementation are needed to counter widespread assumptions about the zero-sum relation between democratization and effective policy making. Unfortunately, democracy is seen as presenting significant risks to sound economic policy, from conceptions of governability crisis in the 1970s (Crozier et al., 1975), through recent doubts about the ability of elected governments in Latin America to impose sufficiently tough measures of monetary and fiscal reform (Williamson, 1990). To the contrary, the gradual, inclusive, and transparent approach to policy making in post-transition Brazil suggests that open, pluralistic governance can produce effective economic policy.

Conceptual innovation is urgently needed to avert the Euro-centrism and liberal-reformism that often bias analysis. $^{42}$ Recent calls for the adoption of parliamentary government or the reform of party and electoral politics echo earlier initiatives of political
Electoral representation in Brazil is more direct, unmediated, fluid, and both tied to political personalities and underlying conceptions of substantive justice.

scientists in their insistence on improving government by concentrating decision-making in the executive. From progressive-era reformers that sought to recast American politics in the first decade of this century, through the 1950 Supplement to the American Political Science Review that called for a more responsible party system, reformers have, paradoxically, sought to centralize governance and exclude the input of popular sectors. Indeed, the consequence of liberal reforms is often to centralize power and distance government from representative and/or electoral institutions. Furthermore, while the object of liberal-reformism changes, the underlying presuppositions about politics appear to remain the same. Direct popular appeals are inferior to rational debate among elites. Representative government is superior to direct democracy. The grievances of individual citizens are often disregarded as excessive particularism and patronage. And institutions of government must function as their organograms describe. Liberal-reformism first defines good government, representation, democracy, or congressional behavior in idealized terms, then seeks to remake reality in this image. This may be a blunt description of working methods, but the difference between this tendency and the positivist tradition of social science could not be greater. Concepts, theories, and hypotheses must constantly be tested through empirical analysis; yet liberal-reformers often seek to remake politics in the light of their theories rather than revise their theories in the light of actual events.

A final conclusion that follows from these concerns is that generalizations about politics need to be based on a wider sample of national and regional 
experiences. ${ }^{43}$ Unless political scientists carefully sort out similarities and differences across nation and region, theories and concepts risk will continue to elevate the European or American experience to the status of a universal paradigm. The political and social sciences need to develop empirically grounded concepts that communicate the variety of new experiences that are currently redefining the risks and opportunities associated with governance through popular inclusion (Collier \& Levitsky, 1997). In this regard, Brazilian political scientists are uniquely situated. For the core issues of post-transition politics will emerge not among the nations at the core of the capitalist system, but from political innovation at the periphery. And no country has the unique combination of cultural, economic, and political creativity at the periphery first described by Mário de Andrade as antropofágica. I therefore conclude by hoping that the participants of the first meeting of the Associação Brasileira de Ciência Política may create a rich variety of concepts and theories about Brazilian democracy that avert the errors of Euro-centrism and the excesses of liberal-reformism.

\section{REFERENCES}

ADORNO, Theodore et al. The authoritarian personality. New York: Harper \& Row, 1950.

BURNHAM, Walter D. Critical elections and the mainsprings of American politics. New York: Norton, 1970. p. 10.

CAMP, Roderic (Ed.). Polling for democracy. public opinion and political liberalization in Mexico. Wilmington, DL: SR Books, 1996

CARRION, Julio. Partisan decline and Presidential popularity: the politics and economics of representation in Peru, 1980-1993. In: METTENHEIM, Kurt von, MALLOY, James (Eds.). Deepening democracy in Latin America. Pittsburgh: University of Pittsburgh Press, 1998.

COLLIER, David, LEVITSKY, Steven. Democracy with adjectives: conceptual innovation in comparative research. World Politics, v. 49, n. 3, p. 430-451, Apr. 1997.

CONAGHAN, Catherine. Public life in the times of Alberto Fujimori. Washington, D.C.: Latin American Program Papers, Woodrow Wilson International Center for Scholars, 1996.
CROZIER, Michael et al. The crisis of democracy. New York: New York University Press, 1975.

FRIEDRICH, Carl. The impact of the American Constitution abroad. Boston: Boston University Press, 1967.

KAUFMAN, Robert. Regionalism, regime transformation, and PRONASOL: the politics of the national solidarity program in four Mexican states. New York: Columbia University Institute for Latin American and Iberian Studies Working Papers, 1996.

LANE, Robert. Political ideology. New York: Free Press, 1962.

LINZ, Juan, VALENZUELA, Arturo (Eds.). The failure of Presidential democracy in Latin America. Baltimore: Johns Hopkins University Press, 1994.

MALLOY, James. Conclusion. In: MALLOY, James, SELIGSON Mitchell (Eds). Authoritarians and democrats in Latin America. Pittsburgh: University of Pittsburgh Press, 1987. p. 235-258.

METTENHEIM, Kurt von (Ed.). Presidential institutions and democratic politics: comparing regional and nationa contexts. Baltimore: Johns Hopkins University Press, 1997.
METTENHEIM, Kurt von, MALLOY, James (Eds.). Deepening democracy in Latin America. Pittsburgh: University of Pittsburgh Press, 1998.

NOELLE-NEUMANN, Elizabeth. The spiral of silence. Chicago: University of Chicago Press, 1984.

O'DONNELL, Guillermo. Illusions about consolidation. Journal of Democracy, v. 7, n. 2, p. 34-51, 1996.

PITKIN, Hanna. The concept of representation. Berkeley, University of California Press, 1968.

SARTORI, Giovanni. Parties and party systems. Cambridge: Cambridge University Press, 1976.

SOUZA, Maria C. C. de. Estado e partidos políticos no Brasil: 1930-1964. São Paulo: Alfa Ômega, 1976.

WILLIAMSON, John. Latin American adjustment: how much has happened? Washington, D.C. Institute for International Economics, 1990

\section{NOTES}

Paper presented to the I Encontro da Associação Brasileira de Ciência Política, 17-20 December 1998, Rio de Janeiro.

1. For a recent cross-regional analysis, see: LINZ, Juan, STEPAN, Alfred. Problems of democratic transition and consolidation. Baltimore: Johns Hopkins University Press, 1996.

2. Note Guillermo O'Donnell's call for positive concepts and theories based on empirical analysis of post-transition experiences in the global south and east. See: O'Donnell (1996)

3. Since the Trilateral Commission report in the mid-1970s, social scientists tend to set democratization and governance in zero-sum terms. See: Crozier et al. (1975).

4. Note the scepticism about democracy and economic policy in: Williamson (1990) and DORNBUSCH, Rudiger, EDWARDS, Sebastian. The macroeconomics of populism in Latin America. Chicago: The University of Chicago Press, 1991

5. On conceptual innovation in comparative political analysis, see: Collier \& Levitsky (1997). On the need for comparative political analysts to construct an empirically grounded, positive theory of democracy in the post-Cold War and post-transition world, see: O'Donnell (1996).
6. On democracy and governance, see: CONAGHAN, Catherine, MALLOY, James. Unsettling statecraft: democracy and neoliberalism in the Central Andes. Pittsburgh: University of Pittsburgh Press, 1994; MARCH, James G., OLSEN, John P. Democratic governance. New York: Free Press, 1995 and DOMINGUEZ, Jorge I., LOWENTHAL, Abraham (Eds.). Constructing democratic governance: Latin America and the Caribbean in the 1990s. Baltimore: Johns Hopkins University Press, 1996.

7. On inertial inflation, see: BRESSER PEREIRA, Luiz C., NAKAMO, Yoshiaki. The Theory of Inertial Inflation: The foundation of economic reform in Brazil and Argentina. Boulder: L. Rienner, 1987

8. See also: LIJPHART, Arend. Parliamentary versus Presidential Government. New York: Oxford University Press, 1992 and STEPAN, Alfred, SKATCH, Cindy. Constitutional frameworks and democratic consolidation: parliamentarism versus presidentialism. World Politics, v. 46, n. 1, p. 1-22 Oct. 1993.

9. On critical elections and realignments in American politics, see: KEY, V. 0 . A theory of critical elections. Journal of Politics, v. 17, p.3-18, 1950 and CHAMBERS, William N., BURNHAM, W. D. The American party systems. New York: Oxford University Press, 1967.
10. Sartori (1976) remains the classic comparative analysis of the emergence, consolidation, and functioning of political party systems.

11. Max Weber notes: "That the plebiscitary 'machine' has developed so early in America is due to the fact that there, and there alone, the executive - this is what mattered the chief office of patronage, was a president elected by plebiscite." (GERTH, Hans, MILLS, C. W. (Eds.). Politics as a vocation. In: WEBER, Max. Essays in Sociology. New York: Oxford University Press, 1946. p. 108). What were the consequences? Weber is also unequivocal: "...the Germans perfected the rational, functional, and specialized bureaucratic organization of all forms of domination from factory to army and public administration. For the time being the Germans have been outdone only in the techniques of party organization, especially by the Americans." (Gerth \& Mills, 1946). See also: OSTROGORSKI, M. I. Democracy and the organization of political parties in the United States and Great Britain. Garden City: Doubleday, 1964 abridged and BRYCE, James. The American Commonwealth. New York: Macmillan, 1907. 
12. Walter D. Burnham argues not only that V. 0 . Key's pathbreaking concept of critical elections provides a broad theory of political change in American history, but also that the wave of populism and party mobilization in the late nineteenth century (reversed by progressive-era legislation) was a lost opportunity for party building and popular inclusion (BURNHAM, Walter D. The current crisis in American politics. New York, Oxford University Press, 1982.)

13. Liberal-reformism has pervaded American politica thought from Woodrow Wilson and progressive-era reformers, through calls for a more responsible two party system in the 1950s. And despite considerable evidence to the contrary, critics of presidentialism in post-transition contexts continue to cite divided government as a vice. See: WILSON, Woodrow. Congressional government: a study in American politics. New York: Houghton Mifflin, 1900, TOWARD a more responsible two party system. American Political Science Review, v. 44, 1950. Supplement and Linz \& Valenzuela (1994).

14. Scales of political conceptualizations are typologies of how individuals think about politics. Since Campbell (CAMPBELL, Angus et al. The American voter. New York, Wiley, 1960) and Converse's ground-breaking work cited below, the accepted level of conceptualization scale contained four categories: ideologues, near ideologues, group interest, nature of the times, and a residual category of no content (CONVERSE, Phillip. The nature of belie systems in mass publics. In: APTER, David (Ed.). Ideology and consent. New York: Free Press, 1964. p. 206-256).

15. See: PAGE, Benjamin, SHAPIRO, Robert. The rational public. Chicago, University of Chicago Press, 1992 and POPKIN, Samuel. The reasoning voter: communication and persuasion in presidential campaigns. Chicago: University of Chicago Press, 1991.

16. Negative definitions, argues O'Donnell (1996, p. 39): "shift attention away from building typologies of polyarchies on the basis of the specific, positively described traits of each type."

17. O'Donnell (1996, p. 38) notes: "these studies (o democratic institutions) presuppose, as their comparative yardstick, a generic and somewhat idealized view of the old polyarchies. The meaning of such a yardstick perplexes me: often it is unclear whether it is something like an average of characteristics observed within the set of old polyarchies, or an ideal type..., or a generalization... or a normative statement of preferred traits."

18. On party-electoral politics during the Empire, see: GRAHAM, Richard. Patronage and politics in nineteenth century Brazil. Stanford: Stanford University Press, 1990; BEIGUELMAN, Paula. A formação política do Brasil. São Paulo, Pioneiro, 1973 and VIANNA, Oliveira. As instituições políticas brasileiras. Rio de Janeiro: Nacional, 1954.

19. On the adoption of federalism during the Old Republic (1889-1930), see: SOUZA, Maria C. C. de. O processo políticopartidário na Primeira República. In: M0TTA, Carlos G. (Ed.) Brasil em perspectiva. São Paulo: Difel, 1984. p. 162-226 and LOVE, Joseph. São Paulo in the Brazilian Federation, 1889-1937. Stanford: Stanford University Press, 1980.

20. Juan Linz insightfully describes the coexistence of directly elected governors and military federal government from 1982-1985 as a situation of diarchy or dual power (LINZ, Juan. The transition from an authoritarian regime to democracy in Spain: some thoughts for Brazilians. Yale University, 1983 (memo). Rather than a means for selecting new civilian political elites, during Brazil's "Long Road of Liberalization" elections served as mechanisms, first for military elites to liberalize their rule, then for negotiations between military leaders and opposition groups. See: SKIDMORE, Thomas. The politics if military rule in Brazil, 1964-1985. New York: Oxford, 1988.

21. On party-electoral politics in post-transition Argentina see: CATTERBERG, Edgardo. Argentina confronts politics: political culture and public opinion in the Argentine transition to democracy. Boulder: Lynn Rienner Publishers, 1991 and GIBSON, Edward L. Class and conservative parties: Argentina in comparative perspective, Baltimore: Johns Hopkins University Press, 1996.
22. Since the dealignment of class and party cleavages in the 1960 s, scholars of European public opinion have struggled to develop new concepts and theories. See: RUSSELL, Dalton et al. Electoral change in the advanced industrial democracies: realignment or dealignment? Princeton: Princeton University Press, 1983 and INGLEHART, Ronald. Culture shift in advanced industrial society. Princeton: Princeton University Press, 1997.

23. On change and transparency in public opinion, see: INGLEHART, Ronald. Aggregate stability and individual level flux in mass belief systems: the level of analysis paradox. American Political Science Review, v. 79, p. 97-116, 1985.

24. On Deutch's rather bucolic model of elite influence as a series of cascading pools and other theories of elite influence according to competitive theories of democracy, see: SARTOR Giovanni. The theory of democracy revisited. Chatham, $\mathrm{NJ}$ : Chatham House, 1987 and DEUTSCH, Karl. The analysis of international relations. Englewood Cliffs: Prentice Hall, 1968. p. 101-110.

25. For example: MARGOLIS, Michael, MAUSER, Gary. Manipulating public opinion: essays on public opinion as a dependent variable. Pacific Grove, CA: Brooks/Cole, 1989 and GINSBERG, Benjamin. The captive public: how mass opinion promotes state power. New York: Basic Papers, 1986.

26. The traditional model of public opinion and voter choice in advanced democracies relies on the following causal sequence: Long-term factors such as political socialization, class-based identities, and party identification mediate (moderate) short-term shifts in public opinion caused by perceptions of economic performance, candidate personality, and new political issues. See: CAMPBELL, Angus et al. The American voter. New York, Wiley, 1960. On the continued influence of this traditional model in current research, see: ASHER, Herbert. Voting behavior research in the 1980s: an examination of some old and new problem areas. In: FINIFTER, Ada (Ed.). Political science: the state of the discipline. Washington, DC: American Political Science Association, 1983.

27. See: KINDER, Donald. Diversity and complexity in American public opinion. In: FINIFTER, Ada (Ed.). Political science: the state of discipline. Washington, DC: American Political Science Association, 1983. A critical contribution toward capturing causal complexity is: PAGE, Benjamin and JONES, Calvin. Reciprocal effects of policy preferences, party loyalties, and the vote. American Political Science Review, v. 73, p. 1071 1089,1979

28. For a review of the "new political history," see: KLEPPNER, Paul. Beyond the "new political history": a review essay. Historical Methods Newsletter, v. 6, p. 17-26, Dec. 1972 Central contributions include: BURNHAM, Walter D. The current crisis in American politics. New York: Oxford University Press, 1982; CONVERSE, Phillip E. Change in the American universe. In: CAMPBELL, Angus, PHILLIP E. (Eds.) The human meaning of social change. New York: Russell Sage Foundation, 1973. KLEPPNER, Paul. The cross of culture: a social analysis of Midwestern politics, 1850-1900. New York: Free Press, 1970. JENSEN, Richard. The winning of the Midwest: social and political conflict, 1888-1896. Chicago: University of Chicago Press, 1971.

29. On differences between European and American politica development, see: HUNTINGTON, Samuel. Political order in changing societies. New Haven: Yale University Press, 1968. Ch. 2 .

30. Weber discusses the passive element in the organization of American politics in: GERTH, Hans, MILLS, C. W. (Eds.). Politics as a vocation. In: WEBER, Max. Essays in Sociology. New York: Oxford University Press, 1946. P. 113 and WEBER, Max.Parliament and Government in a Reconstructed Germany. In: WEBER, Max. Economy and society. Berkeley:University of California Press,1978. p.1398-1402.

31. On the Worker's Party, see: KECK, Margaret. The Workers' Party and democratization in Brazil. New Haven: Yale University Press, 1992.

32. According to Brazilian electoral legislation, executive contests require a second round unless a candidate wins over 50 percent plus one of valid votes (not including blank/nul ballots), or unless the votes received by a candidate exceed the sum of votes for all other candidates.
33. Since 1932 the Brazilian electoral code has used this mechanism first proposed by Assis Brasil in 1897 (Democracia representativa. Rio de Janeiro: Imprensa Nacional, 1931).

34. On electoral stability and change in Europe, see: BARTOLINI, S., MAIR, Peter. Identity, competition and electoral availability. Cambridge: Cambridge University Press, 1990.

35. Caveats are in order. First, far from a single pattern throughout Latin America, differences matter. Educated publics in Argentina and Chile may be closer to European voters. See: VALENZUELA, J. Samuel, SCULLY, Timothy. Electoral choices and the party system in Chile: continuities and changes at the recovery of democracy. Comparative Politics, v. 29, n.4, July 1997. More established party systems such as Colombia and Venezuela may retain have produced strong party identification among voters. See: BALOYRA, Enrique. Deepening democracy with dominant parties and presidentialism: the Venezuelan regime in a period of turbulence. In: Mettenheim \& Malloy (1998) and HARTLYN, Jonathan. The politics of coalition rule in Colombia. Cambridge: Cambridge University Press, 1988. And electora politics in Central America appears to depend less on media images and other patterns typical of mass society (DOMINGUEZ, Jorge I., LINDENBERG, Marc. Democratic transitions in Central America. Gainesville, FL: University Press of Florida, 1997. Nonetheless, direct popular appeals through the media appear to increasingly influence voters in the region. See: SKIDMORE, Thomas (Ed.). Television, politics, and the transition to democracy in Latin America. Baltimore: Johns Hopkins University Press, 1993.

36. On post-transition economic policy and democracy, see: NELSON, Joan (Ed.). Intricate links: democratic politics and market reform in Latin America and Eastern Europe. New Brunswick, NJ: Transaction, 1994 and HAGGARD, Stephan, KAUFMAN, Robert R. The political economy of democratic transitions. Princeton: Princeton University Press, 1995

37. While social pacts were critical for imposing economic adjustment in Mexico and Argentina, Brazil lacks the corporatist organizations or political parties capable of enforcing pacts. Collor's appeals for a national understanding with labor and business also failed because of poor political timing; the government sought to organize a pact as inflation increased and the recession deepened. On pacts, see: O'DONNELL, Guillermo, SCHMITTER, Philippe, WHITEHEAD, Laurence (Eds.). Transitions from authoritarian rule: Southern Europe and Latin America. Baltimore: Johns Hopkins University Press, 1986 and HIGLEY, Jon, GUNTHER, Richard (Eds.). Elites and democratic consolidation in Latin America and Southern Europe. Cambridge: Cambridge University Press, 1992

38. On the impeachment process, see: WEYLAND, Kurt. The rise and fall of President Collor and its impact on Brazilian democracy. Journal of Interamerican Studies and World Affairs, v. 35, n. 1, p. 1-37, 1993

39. On the plebiscite to choose form of government, see: LAMOUNIER, Bolivar. Brazil: Towards Parliamentarism? In: Linz \& Valenzuela (1994).

40. Estimates from the Fundação Instituto de Pesquisas Econômicas da Universidade de São Paulo and Departamento Intersindical de Estatística e Estudos Socioeconômicos (Dieese) reported in Folha de S. Paulo, Mar. 26, 1995, Section 2, p. 5 .

41. On inertial inflation, see: BRESSER PEREIRA, Luiz C. NAKAMO, Yoshiaki. The Theory of Inertial Inflation: the foundation of economic reform in Brazil and Argentina. Boulder: L. Rienner, 1987.

42. On liberal assumptions, see: PACKENHAM, Robert A Liberal America and the Third World: political development ideas in foreign aid and social science. Princeton: Princeton University Press, 1973

43. On the implications of national and regional contexts for comparative political analysis, see: Mettenheim (1997). 